\title{
Interferon-alpha (IFN- $\alpha$ ) production by human intestinal mononuclear cells. Response to virus in control subjects and in Crohn's disease
}

\author{
M R Capobianchi, S Fais, F Mercuri, M Boirivant, F Dianzani, F Pallone
}

\begin{abstract}
The virus induced production of interferon alpha by human intestinal lamina propria mononuclear cells was investigated. Intestinal and autologous peripheral cells from control subjects and patients with Crohn's disease were cultured in vitro with and without stimulation with the Newcastle disease virus. Interferon alpha was measured and characterised in the culture supernatants after 12 hours and the kinetics of production was evaluated over the following four days of culture. No detectable interferon alpha was found in cultures of unstimulated intestinal and autologous peripheral mononuclear cells from controls and Crohn's disease whereas interferon alpha was released in all cultures stimulated with the virus. In all 12 hours experiments in both groups, virus stimulated intestinal mononuclear cells yielded significantly less interferon alpha than the autologous peripheral cells. The kinetics experiments showed that control intestinal mononuclear cells appeared to be poorly responsive to virus stimulation showing a release of interferon alpha significantly lower than that of the autologous peripheral cells. The interferon alpha release at day 4 by control cells (either intestinal or peripheral) did not differ from that measured after the first 12 hours. In contrast, the interferon alpha produced by Crohn's disease cells progessively increased during the culture period and the amount of interferon alpha measured at day 4 was significantly higher than that released at 12 hours. These data suggest that normal human intestinal mononuclear cells are down regulated in their capability of producing interferon alpha and that in Crohn's disease their activation for this function is enhanced. These data also suggest that in Crohn's disease intestinal mononuclear cells exhibit a transient hyporesponsiveness to in vitro stimulation possibly related to massive in vivo exposure to interferon alpha inducers.
\end{abstract}

The production of interferons is a host defence mechanism involved in the control of viral infections. ${ }^{12}$ Both cellular and humoral immunity are influenced by interferons and their role has also been postulated in immune disorders. ${ }^{3}$ The production and secretion of the interferon proteins can be stimulated by a number of inducers, including foreign substances and cytokines..$^{3-6}$ The production of alpha and beta interferon is a specialised function of macrophages, B lymphocytes and fibroblasts, whereas interferon gamma is produced by activated T cells. ${ }^{78}$
Because the human gut mucosa is the site of continuous interaction between the local immune system and the luminal content rich in interferon inducers, it is conceivable that interferons are physiologically produced at the mucosal level. Very little is known about the mode of interferons production and the cell type producing interferon in the human gut mucosa. ${ }^{910}$ It is suggested that interferons are produced in minute amounts in restricted areas and locally used, similar to other autocrine and paracrine secretions. ${ }^{11-13}$ While interferon gamma production has been shown at the mucosal level in response to adequate stimulation, ${ }^{910}$ no data are currently available concerning the production of interferon alpha by the human intestinal lamina propria mononuclear cells.

A heightened state of immune activation has been shown in Crohn's disease both in the peripheral blood and in the gut mucosa. ${ }^{1+21}$ There is also evidence that the production of interferon gamma at the mucosal level is altered. ${ }^{10}$ We have therefore investigated the definition of interferon alpha response in normal intestinal lamina propria mononuclear cells in man to determine whether this response is altered in chronic inflammatory states such as Crohn's disease. For this purpose the interferon alpha production by lamina propria mononuclear cells and autologous peripheral blood cells from controls and Crohn's disease patients was established by stimulating these cells with the interferon alpha inducer Newcastle disease virus. known to preferentially stimulate monocytes. $^{22-24}$

\section{Methods}

\section{ISOLATION OF LAMINA PROPRIA MONONUCLEAR} CELLS

Mucosal samples were obtained from the involved areas of surgical specimens of 11 patients with Crohn's disease of the colon. The disease was active in all patients as defined by clinical and laboratory parameters ${ }^{25} 26$ and the indication for surgery was the failure of medical treatment in all patients which consisted of high dose steroids. Treatment was stopped one week before surgery in all cases. The histology of the resected specimens showed the typical pattern of Crohn's disease ${ }^{27}$ Contiguous areas of the specimens used showed active inflammatory changes in the mucosa and submucosa. As controls, samples from the macroscopically and microscopically uninvolved areas of 12 resected specimens were used (nine colonic cancer, two diverticular disease, one severe chronic constipa- 
tion). In none of these was there evidence of inflammation.

The colonic mucosa was dissected within one hour of resection and lamina propria mononuclear cells were isolated using the DTTEDTA-collagenase method. ${ }^{192}$ Strips of the mucosa (8-9g total weight) were washed in Hank's balanced salt solution free of calcium and magnesium (HBSS-CMF) (Flow Lab, UK). The mucosal strips were then washed in HBSS-CMF containing $1 \mathrm{mM}$ dithiothreitol (Sigma Chem, USA) and antibiotics (penicillin $100 \mathrm{IU} / \mathrm{ml}$, streptomycin $100 \mu \mathrm{g} / \mathrm{ml}$, gentamycin $50 \mu \mathrm{g} / \mathrm{ml}$ and fungizone $25 \mu \mathrm{g} / \mathrm{ml}$ ) for 15 minutes at room temperature. After three washings in Hank's balanced salt solution free of calcium and magnesium the mucosal strips were chopped in approximately $3 \times 3 \mathrm{~mm}$ pieces. These pieces were then incubated four to five times in Hank's balanced salt solution free of calcium and magnesium containing $0.75 \mathrm{mM}$ ethylene diaminetetraacetric acid (EDTA) (Sigma Chem USA), $10 \mathrm{mM}$ Hepes buffer and antibiotics for 45 minutes at $37^{\circ} \mathrm{C}$ in humid $5 \% \mathrm{CO}_{2}$ atmosphere to remove epithelial cells. After two washes the mucosal pieces were incubated for 10-13 hours at $37^{\circ} \mathrm{C}$ in humid $5 \% \mathrm{CO}_{2}$ atmosphere in complete medium containing $25 \mathrm{IU} / \mathrm{ml}$ purified collagenase (Sigma VII, Sigma Chem USA). The supernatant was then collected and washed twice in Hank's balanced salt solution free of calcium and magnesium, the pellet resuspended in complete medium and then layered on a Ficoll-Paque density gradient. The resulting lamina propria mononuclear cells were counted and checked for viability using $0 \cdot 1 \%$ trypan blue (viability ranged between $85 \%$ and $95 \%$ ). The relative proportion of cell subpopulations were consistently within the following ranges by indirect immunofluorescence: ${ }^{29} \mathrm{CD} 3+58-65 \%$; CD4+ 35-42\% CD8+ 22-30\%; monocytes (CD11+) 7-14\%: B lymphocytes (CD19+) 8-14\%. Autologous peripheral blood mononuclear cells were obtained from venous heparinised blood layered on a Ficoll-Paque (Pharmacia, Sweden) density gradient.

CULTURES OF LAMINA PROPRIA MONONUCLEAR CELLS AND PERIPHERAL BLOOD MONONUCLEAR CELLS

Lamina propria mononuclear cells and peripheral blood mononuclear cells were resuspended in complete medium at a concentration of $1 \times 10^{6}$ cells $/ \mathrm{ml}$ and cultured in flat-bottomed 24 well culture plates (Falcon Plastic, USA) with and without the addition of the Newcastle disease virus ( $10 \mathrm{HA} / 10^{6}$ cells). ${ }^{22}$ After $12,24,48$, and 72 hours culture supernatants were collected and stored at $-80^{\circ} \mathrm{C}$.

Experiments were also performed in order to determine whether cells spontaneously released soluble factors capable of modulating the interferon response. In these experiments Newcastle disease virus and staphylococcal enterotoxin B stimulated normal peripheral blood mononuclear cell cultures were seeded in the presence of supernatants (dilutions 1:3, 1:10) from 24 hours unstimulated cultures of either controls or Crohn'sdiseaselamina propria mononuclearcells.
INTERFERON TITRATION AND CHARACTERISATION Interferon was measured and characterised in culture supernatants at $12,24,48$, and 72 hours. Interferon titre was determined by inhibition of Sindbis virus haemagglutinin yield after a single growth cycle as previously described. ${ }^{30}$ Briefly, serial dilutions $(0.5 \mathrm{Log}$ ratio) of supernatants were added to triplicate wells of human amnion Wish cells and incubated overnight. Dilutions were then removed, the culture rinsed and challenged with Sindbis virus at multiplicity of infection of 100:1. Twenty four hours later the protection from viral replication was determined by cytopathic effect reading and by titration of virus yield, measured by haemagglutination with goose red cells. In each titration a preparation of standard interferon alpha (NIH Ga 23-902-530) was run and the titres were adjusted, when needed, to the standard value. Usually this was not necessary, as in our system 1 unit of the international standard gives $0.5 \mathrm{Log}$ of viral inhibition, corresponding to full sensitivity of the assay system. Interferon activity was expressed as $\log _{10}$ of international units/ml ( $\log$ $\mathrm{IU} / \mathrm{ml}$ ). Representative interferon samples were characterised as alpha type by acid treatment and neutralisation with specific antibodies (polyclonal anti interferon alpha, Shering Co, USA; polyclonal anti interferon beta, Sclavo, Italy; monoclonal anti interferon gamma, Hoffman-La Roche, Switzerland) as previously described. ${ }^{22}$

\section{STATISTICAL ANALYSIS}

The non-parametrical two tailed Wilcoxon's rank-sum-test and the Student's $t$ test were used as appropriate for the statistical analysis of the data.

\section{Results}

No interferon alpha was detected in the culture supernatants of unstimulated lamina propria mononuclear cells and peripheral blood mononuclear cells from both Crohn's disease and controls. When the cell suspensions from either groups were stimulated with Newcastle disease virus, interferon alpha was detected in all the culture supernatants tested 12 hours later. Lamina propria mononuclear cells from both groups appeared to produce less interferon alpha than the autologous lamina propria mononuclear cells (Fig 1). The response of both lamina propria mononuclear cells and peripheral blood mononuclear cells from Crohn's disease patients appeared, however, to be significantly lower than that of the corresponding (either mucosal or peripheral) control cells $(p<0.01)($ Fig 1$)$.

The kinetics of interferon alpha response of lamina propria mononuclear cells and peripheral blood mononuclear cells from control subjects are shown in Figure 2. In both cell suspensions interferon alpha production was maximal at 12 hours, remaining at a plateau during the subsequent culture period. The amount of interferon alpha released at the end of the four days culture by lamina propria mononuclear cells $(1.5(0.5)$ $\log \mathrm{IU} / \mathrm{ml}$ ) and peripheral blood mononuclear cells $(2 \cdot 2(0 \cdot 2) \log \mathrm{IU} / \mathrm{ml})$ did not differ from that measured after the first 12 hours incubation $(1 \cdot 2$ 
Figure 1: IFN-alpha production 12 hours after stimulation in cultures of intestinal (LPMNC)

(dashed columns) and peripheral (PBMNC) (empty columns) mononuclear cells from controls and Crohn's disease.

The values are the mean of all the experiments $(12$ control individual and 11 Crohn's disease patients). Vertical bars represents 1 SEM. (See Table for abbreviations)

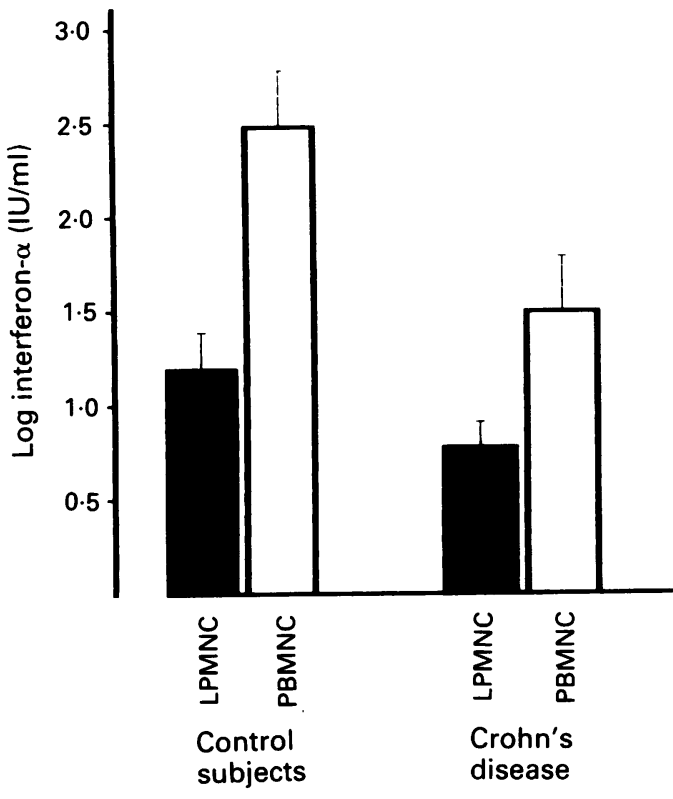

$(0 \cdot 2)$ and $2 \cdot 5(0 \cdot 3)$, respectively). As shown in Figure 2, the amount of interferon alpha released by lamina propria mononuclear cells at each time interval was significantly lower than that released by the autologous peripheral blood mononuclear cells $(\mathrm{p}<0.01)$.

In contrast, interferon alpha production by either lamina propria mononuclear cells and peripheral blood mononuclear cells from patients with Crohn's disease continued to significantly increase after 48 hours incubation (Fig 3). In lamina propria mononuclear cells and peripheral blood mononuclear cells from Crohn's disease patients the interferon alpha measured after the four days culture $(2.0(0.6)$ and $2.5(0.6)$, respectively) was significantly higher than that released at 12 hours $(0.75(0.1)$ and $1.5(0.3)$, respectively) (Fig 3 ). As for the control mononuclear cells, the amount of interferon alpha released by Crohn's disease lamina propria mononuclear cells at 24,48 , and 72 hours was significantly lower than that released by the autologous peripheral blood mononuclear cells, but at the end of the culture period there was no significant difference between lamina propria mononuclear cells and peripheral blood mononuclear cells in terms of interferon alpha yield (Fig 3).

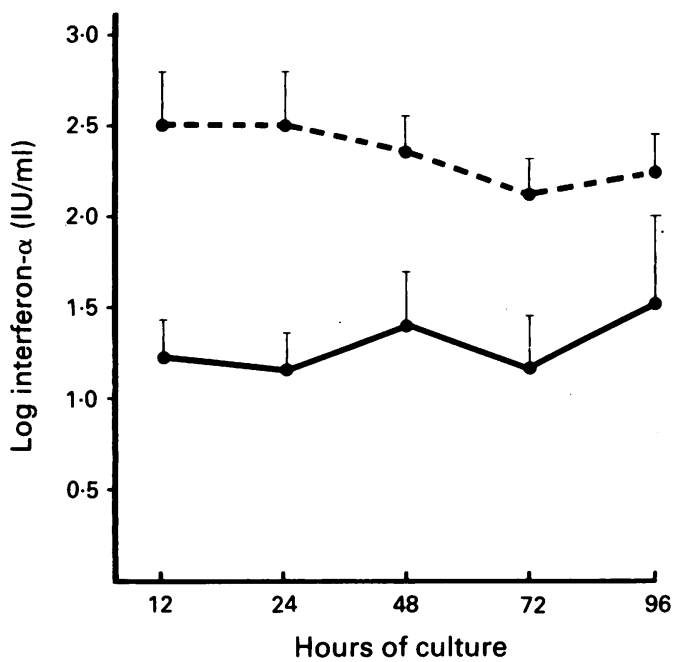

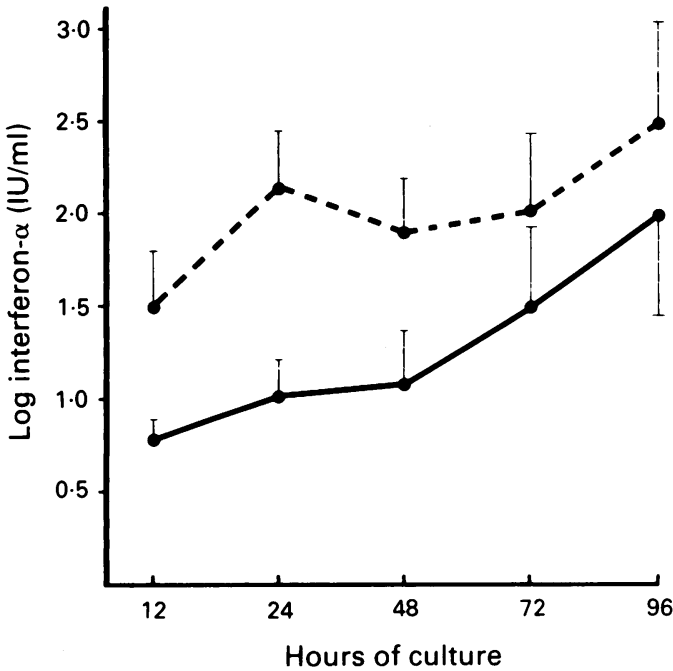

Figure 3: Kinetics of the NDV induced in vitro release of IFN alpha by cultured LPMNC (solid line) and PBMNC (broken line) from Crohn's disease patients. Each point in the curves is the mean of all experiments (11 Crohn's disease patients). Vertical bars represents 1 SEM. (See Table for abbreviations)

Experiments were done to determine whether the delayed interferon alpha production by cells from patients with Crohn's disease was because of the soluble inhibitors released by these cells. To this purpose normal peripheral blood mononuclear cells were stimulated to produce interferon alpha and interferon gamma in the presence of supernatants from 24 hours culture (dilution 1:3 and 1:10) of either controls and Crohn's disease lamina propria mononuclear cells. As shown in the Table, no significant difference was observed in the yield of interferon alpha when the normal peripheral blood mononuclear cell cultures were stimulated in the presence of medium conditioned by either lamina propria mononuclear cells.

\section{Discussion}

This study provides evidence for a virus induced interferon alpha response by intestinal mononuclear cells of control individuals and Crohn's disease patients. The various cell populations studied appear to differ in terms of both the amount of interferon alpha produced and the kinetics of interferon alpha release. Two major findings emerged from the present experiments. First, the response of intestinal mononuclear cells to Newcastle disease virus was less pronounced as compared with the autologous peripheral cells of both controls and Crohn's disease. Second, the kinetics of interferon alpha production by Crohn's disease cells, either peripheral or intestinal, was different from that of the corresponding control cells.

Lamina propria mononuclear cells appeared to respond less than peripheral blood mononuclear cells. It is unlikely that this was because of defects in the functional properties of the cells caused by the collagenase treatment. In fact, it has been previously reported that the treatment of mononuclear cells with proteases does not affect the interferon production. ${ }^{31}$ Moreover, the supernatants from either Crohn's disease or control lamina propria mononuclear cells were 
Interferon yield in 48 hours cultures of normal PBMNC run in the presence of either $S E B$ or $N D V$ with and without the addition of 24 hours conditioned medium from controls and $C D$ LPMNC (dilutions $1: 3$ and $1: 10$ )

\begin{tabular}{|c|c|c|c|c|c|}
\hline \multirow[b]{3}{*}{ Inducer } & \multicolumn{5}{|c|}{ Interferon yield (mean (SEM) Log IU/ml) } \\
\hline & \multirow{2}{*}{$\begin{array}{l}\text { Unconditioned } \\
\text { medium }\end{array}$} & \multicolumn{2}{|c|}{ Control LPMNC medium } & \multicolumn{2}{|c|}{$C D L P M N C$ medium } \\
\hline & & $1: 3$ & $1: 10$ & $1: 3$ & $1: 10$ \\
\hline $\begin{array}{l}\text { None } \\
\text { SEB } \\
\text { NDV }\end{array}$ & $\begin{array}{l}<1 \\
\quad 2 \cdot 8(0 \cdot 2) \\
3 \cdot 0(0 \cdot 3)\end{array}$ & $\begin{array}{l}<1 \\
\quad 2 \cdot 8(0 \cdot 3) \\
3 \cdot 2(0 \cdot 4)\end{array}$ & $\begin{array}{l}<1 \\
2.7(0.3) \\
2.9(0.4)\end{array}$ & $\begin{array}{l}<1 \\
3.0(0.4) \\
2.9(0.4)\end{array}$ & $\begin{array}{l}<1 \\
3 \cdot 1(0 \cdot 4) \\
3 \cdot 1(0 \cdot 3)\end{array}$ \\
\hline
\end{tabular}

$\mathrm{PBMNC}=$ peripheral blood mononuclear cells; $\mathrm{SEB}=$ staphylococcal enterotoxin $\mathrm{B}$;

$\mathrm{NDV}=$ Newcastle disease virus; $\mathrm{CD}=$ Crohn's disease; $\mathrm{LPMNC}=$ lamina propria mononuclear cells; IFN $=$ interferon.

unable to inhibit the interferon alpha production by normal peripheral blood mononuclear cells suggesting that the reduced interferon alpha production by lamina propria mononuclear cells was not caused by the soluble inhibitory substances present in the culture fluids. It is also unlikely that the hyporesponsiveness to Newcastle disease virus exhibited by lamina propria mononuclear cells in this study was the result of a poor capability of these cells to respond to stimulation. In fact, the response of both cancer and Crohn's disease lamina propria mononuclear cells to the interferon gamma inducer staphylococcal enterotoxin B did not appear to significantly differ from that of the autologous peripheral blood mononuclear cells, as previously described. ${ }^{10}$

There is circumstantial evidence that in man macrophages and B lymphocytes are capable of releasing interferon alpha and that the cellular source of the interferon alpha response is largely determined by the mode of stimulation. ${ }^{4}$ Previous studies performed with variously enriched subpopulations of peripheral mononuclear cells have shown that free virions selectively induce interferon alpha production by macrophages, while B lymphocytes are induced to release interferon alpha by virus infected cells. ${ }^{22-2432-34}$ As in this study we have used live virus as the interferon alpha inducer we can reasonably assume that the cellular source of interferon alpha was mostly the macrophages, although it cannot be completely ruled out that Newcastle disease virus infected macrophages may have induced some interferon alpha production in $\mathrm{B}$ cells. Evidence has been recently provided that in the normal human colonic mucosa the macrophages are 'down regulated' in their ability to exert different immune functions - namely, normal human colonic macrophages are neither able to express IL-2 receptors nor to undergo respiratory burst in response to interferon gamma. ${ }^{35}$ Furthermore, a defective IL- $1 \beta$ production by these cells in response to lipopolysaccharide has also been reported..$^{37}$ Thus, the observation that control lamina propria mononuclear cells responded to interferon alpha inducers less than the autologous peripheral blood mononuclear cells may well be related to the down regulation of normal mucosal macrophages.

The kinetics of interferon alpha release by Crohn's disease cells either peripheral or intestinal, was different from that of the corresponding control cells. The amount of interferon alpha produced at 12 hours by Crohn's disease cells was significantly lower than that produced by control cells, remained fairly stable from 12 to 48 hours, and increased significantly from 48 to 96 hours. These data would suggest that Crohn's disease cells exhibited a transient hyporesponsiveness to stimulation with Newcastle disease virus. The production of interferon alpha is a normally repressed genetic function of the cells. The genetic information for the interferon proteins is contained in a number of normally unexpressed genes. ${ }^{38}{ }^{39}$ When cells are induced to express interferon genes an increased transcription of the appropriate interferon genes rapidly occurs by a process not requiring protein synthesis. Subsequently transcription ceases, interferon mRNA is degraded and interferon production ceases..$^{39}$ As a consequence, the exposure to interferon inducers is followed by a transient (up to 48 hours) hyporesponsiveness that is, the cells are refractory to further stimulation. ${ }^{40}$ In fact, in the inflamed intestinal mucosa and submucosa of patients with Crohn's disease the infiltrating mononuclear cells are in vivo continuously exposed to a variety of stimuli, including viral and non-viral microbial agents capable of inducing the production of interferon alpha. ${ }^{41-43}$ Thus, in Crohn's disease the activation of interferon alpha producing cells is enhanced in the gut mucosa exhibiting a transient hyporesponsiveness to in vitro stimulation. These findings may also be related to the heightened state of immune activation occurring in Crohn's disease both in the peripheral blood and in the diseased gut ${ }^{15192135-37}$ which may well contribute to the disregulation of interferon alpha production as previously shown for the production of interferon gamma and other cytokines. 910374445

This work was supported by grants from the Fondazione Instituto Pasteur-Cenci Bolognetti (FD) and from the Ministero della
Pubblica Instruzione (MRC, FD, FP). The assistance of M Termine is gratefully acknowledged.

1 Baron S, Dianzani F, Stanton GJ, Fleishmann WR Jr. The interferom system: a current review to 1987. Austin, USA: interferon system: a current review
University of Texas Press, 1987.

2 Kirchner $\mathrm{H}$. The interferon system as an integral part of the defense system against infections. Antiv Res 1986; 6: 1-17.

3 Hooks JJ, Moutsopoulos HM, Notkins AL. Circulating interferon in human autoimmune disease. Tex Rep Biol Med 1981; 41: 164-7.

4 Dianzani F, Capobianchi MR. Mechanism of induction of alpha interferon. In: Baron S, Dianzani F, Stanton GJ, Fleishmann WR Jr, eds. The interferon system. Austin, USA: University of Texas Press, 1987: 21-30.

5 Marcus PI. Interferon induction, and its suppression by viruses. In: Baron S, Dianzani F, Stanton GJ, Fleishmann WR Jr, eds. The interferon system. Austin, USA: University of Texas Press, 1987: 41-50.

6 Weigent DA, Langford MP, Smith EM, Blalock JE, Stanton GJ. Human B lymphocytes produce leukocytes interferon after interaction with foreign cells. Infect Immun 1981; 32: after inter.

7 Kirchner H, Salas $M$. Interferon production by leucocytes. In: Baron S, Dianzani F, Stanton GJ, Fleshmann WR Jr, eds. The interferon system. Austin, USA: University of Texas Press, 1987: 309-17.

8 Lebon P, Commoy-Chevalier MJ, Robert-Galliot B, Chany C. Different mechanisms for alpha and beta interferon induction. Virology 1982; 119: 504-7

9 Lieberman BY, Fiocchi C, Youngman KR, Sapatnekar WK Proffitt MR. Interferon production by human intestinal mucosal mononuclear cells: decreased levels in inflammatory bowel disease. Dig Dis $S c i$ 1988; 33: 1297-304.

10 Fais S, Capobianchi MR, Pallone F, Di Marco P, Boirivant M Dianzani F, Torsoli A. Spontaneous release of interferongamma by intestinal lamina propria lymphocytes in Crohn's disease. Kinetics of in vitro response to interferon-gamma inducers. Gut 1991; 32: 403-7.

11 Bocci V. Distribution, catabolism and pharmacokinetics of interferons. In: Finter NB, Oldham RK, eds. Interferon, vo 4: in vivo and clinical studies. Amsterdam: Elsevier, 1985: 47-72. 
12 Bocci V. The physiological interferon response. In: Baron S, Dianzani F, Stanton GJ, Fleishmann WR Jr, eds. The interferon system. Austin, USA: University of Texas Press, 1987: 177-86.

13 Bocci $\mathrm{V}$. Role of interferon produced in physiological conditions. A speculative review. Immunology 1988; 64: 1-9.

14 Pallone F, Montano S, Fais S, Boirivant M, Signore A, Pozzilli P. Studies on peripheral blood in Crohn's disease. Circulating activated T cells. Scand 7 Gastroenterol 1983; 300: 267-9.

15 Fais S, Pallone F, Squarcia O, Boirivant M, Pozzilli P. T cell early activation antigens in Crohn's disease. $\mathcal{F}$ Clin Lab Immunol 1985; 16: 75-6.

16 Raedler A, Fraenkel S, Klose G, Seyfarth K, Thiele HG. Involvement of the immune system in the pathogenesis of Involvement of the immune system in the pathogenesis of
Crohn's disease. Expression of the T9 antigen on peripheral Crohn's disease. Expression of the T9 antigen on peripheral
immunocytes correlates with the severity of the disease. immunocytes correlates with the

17 Boirivant M, Quintieri F, Pugliese O, Famulazo F, Fais S, Pallone F. A limiting-dilution analysis of activated circulating B cells in Crohn's disease. $\mathcal{f}$ Clin Immunol 1990; 10: 128-34.

18 Pallone F, Matricardi PM, Squarcia O, Fais S, Le Moli S, Boirivant M, Paoluzi P, D'Anulo R. Raised serum levels of IgM-rheumatoid factor and anti-F(ab')2 autoantibodies in patients with active inflammatory bowel disease. $₹$ Clin $L a b$ Immunol 1986; 19: 175-80.

19 Pallone F, Fais S, Squarcia O, Biancone L, Pozzilli P, Boirivant $M$. Activation of peripheral and intestinal lamina propria lymphocytes in Crohn's disease. In vivo state of activation and in vitro response to stimulation as defined by the expression of early activation antigens. Gut 1987; 28 : 745-53.

20 Fais S, Pallone F, Squarcia O, Biancone L, Ricci F, Paoluzi P, Boirivant M. HLA-DR antigens on colonic epithelial cells in inflammatory bowel disease. Relation to the state of activation of lamina propria lymphocytes and to the epithelia expression of other surface markers. Clin Exp Immunol 1987; 68: 605-12.

21 Schreiber S, Nash GS, Bertovich M, MacDermott RP. Activation of human lamina propria mononuclear cells in Activation of human lamina propria mononuclear cells in inflammatory bow

22 Capobianchi MR, Facchini J, Di Marco P, Antonelli G Dianzani $F$. Induction of alpha-interferon by membrane interaction between virus surface and peripheral blood mononuclear cells. Proc Soc Exp Biol Med 1985; 178: 551-6.

23 Capobianchi MR, Malavasi F, Di Marco P, Dianzani F. Differences in the mechanisms of induction of interferonalpha by herpes simplex virus and herpes simplex virusinfected cells. Arch Virol 1988; 103: 219-29.

24 Capobianchi MR, De Marco F, Di Marco P, Dianzani F. Acidla-able human interferon alfa production by peripheral blood mononuclear cells stimulated by HIV-infected cells. Arch Virol 1988; 99: 9-19.

25 Pallone F, Ricci R, Boirivant M, Montano S. Measuring the activity of Crohn's disease. Ital $\mathcal{F}$ Gastroenterol $1981 ; 13$ : $51-3$.

26 Harvey RF, Bradshaw JM. A simple index of Crohn's disease activity. Lancet 1980; i: 514

27 Riddel RH. Pathology of idiopathic inflammatory bowe disease. In: Kirsner JB, Shorter RG, eds. Inflammatory bowel disease. Philadelphia, USA: Lea \& Febiger, 1988: 329-50.

28 Bull DM, Bookman MA. Isolation and functional characterization of human mucosal lymphoid cells. 7 Clin Invest 1977 59: 966-74.
29 Squarcia P, Fais S, Boirivant M, Di Paolo MC, Marcheggiano $A$, Iannoni $C$, et al. Phenotypes and spontaneous immunoglobulin production in mononuclear cells suspensions isolated from colonic biopsies of patients with mild active and quiescent ulcerative colitis. Gastroenterol Clin Biol 1991; 15: 194-8.

30 Stanton GJ, Langford MJ, Dianzani F. Virus yield reduction assay for interferon by titration of Sindbis virus hemagglutinin. Meth Enzymol 1981; 78: 351-7.

31 Tsukui $\mathrm{K}$, Miura T, Tokunaga E. Treatment of human peripheral blood leukocytes with proteases does not affect peripheral blood leuk interen production. Infect Immun 1984; 43: 822-4.

32 Roberts NJ Jr, Douglas RG Jr, Simons RM, Diamond ME. Virus-induced interferon production by human macroirus-induced interferon production

33 Saksela E, Virtanen I, Hovi T, Secher DS, Cantell K. Monocytes is the main producer of human leukocytes alphainterferon following Sendai virus induction. Prog Med Virol 1984; 30: 78-86.

34 Brehm G, Kirchner H. Analysis of the interferons induced in mice in vivo and in macrophages in vitro by Newcastle Disease Virus and by Polyinosinic-Polycytidylic acid. F Interf Res 1986; 6: 21-8.

35 Mahida YR, Wu K, Patel S, Jewell DP. Interleukin 2 receptor expression by macrophages in inflammatory bowel disease. Clin Exp Immunol 1988; 74: 382-6.

36 Mahida YR, Wu K, Jewell DP. Respiratory burst activity of intestinal macrophages in normal and inflammatory bowel intestinal macrophages in norm

37 Mahida YR, Wu K, Jewell DP. Enhanced production of interleukin $1 \beta$ by mononuclear cells isolated from mucosa with active ulcerative colitis and Crohn's disease. Gut 1989, 30: $835-8$.

38 Trotta PP, Narula SK. Interferon genes. In: Barori $S$, Dianzani F, Stanton GJ, Fleishmann WR Jr, eds. The interferon system. Austin, USA: University of Texas Press, 1987: $137-48$.

39 Taylor JL, Grossberg SE. Recent progress in interferon research: molecular mechanisms of regulation, action and virus circumvention. Virus Res 1990; 15: 1-26.

40 Stringfellow DA. Regulation of interferon production and hyporesponsiveness. In: Baron S, Dianzani F, Stanton GJ, Fleishmann WR Jr, eds. The interferon system. Austin, USA: University of Texas Press, 1987: 83-90.

41 Smith EM, Johnson HM, Blalock JE. Staphylococcus aureus protein $\mathrm{A}$ induces the production of interferon-alpha in human lymphocytes and interferon alpha/beta in mouse spleen cells. F Immunol 1983; 130: 773-6.

42 Weigent DA, Stanton GJ, Baron S. Nonviral microbia inducers of interferon. In: Baron S, Dianzani F, Stanton GJ, Fleishmann WR Jr, eds. The interferon system. Austin, USA University of Texas Press, 1987: 63-70.

43 Capobianchi MR, Lorino G, Lun MT, Mancini C, Di Marco $P$, Dianzani $F$. Membrane interactions involved in the induction of interferon-alpha by Mycoplasma pneumoniae. Antiv Res 1987; 8: 115-24.

44 Fiocchi C, Hilfiker ML, Youngman KR, Doerder NC, Finke $\mathrm{JH}$. Interleukin 2 activity of human intestinal mucosa mononuclear cells. Decreased levels in inflammatory bowe disease. Gastroenterology 1984; 86: 734-42.

45 MacDonald TT, Hutchings P, Choy MY, Murch S, Cooke A Tumor necrosis factor-alpha and interferon-gamma production measured at the single cell level in normal and inflamed human intestine. Clin Exp Immunol 1990; 81: 301-5. 